\title{
Sakarya İlinde Fındık Üretimi Yapan İşletmelerin Karlıık Analizi ve Pazarlama Yapısı
}

\author{
Vedat Dağdemir* \\ Özge YILDIZ \\ Atatürk Üniversitesi, Ziraat Fakültesi, Tarım Ekonomisi Bölümü, 25240, Erzurum \\ (*Sorumlu yazar e-mail: dagdemir@atauni.edu.tr)
}

Geliş Tarihi : 17.02.2017

Kabul Tarihi : 15.04.2017

\begin{abstract}
ÖZET: Çalışmada, Sakarya ilinde findık üretimi yapan işletmelerin karlılık analizinin yapılması ve pazarlama marjının hesaplanması amaçlanmıştır. Sakarya'nın 6 ilçesinde findık üretimi yapan 152 adet tarım işletmesinde anket yapılmıştır. İşletme başına düșen findık bahçesi büyüklüğü 12.13 da olarak bulunmuștur. Kabuklu findık ortalama verimi $141.61 \mathrm{~kg} / \mathrm{da}$, üretim masrafları toplamı $714.27 \mathrm{£} / \mathrm{da}$, değișir masraflar toplamı 596.30 €/da, kabuklu findık maliyeti ise 5.044 €/kg olarak hesaplanmıştır. Dekara brüt kar 1440.05 €, net kar ise 1322.08 € bulunmuştur. Pazarlama marjı kabuklu findık için 7.62 €/kg, iç findık için ise 21.44 €/kg hesaplanmıştır.
\end{abstract}

Anahtar kelimeler: Fındık, brüt kar, net kar, pazarlama marjı, Sakarya

\section{Profitability Analysis and Marketing Structure of Hazelnut Establishments in Sakarya}

\begin{abstract}
In the study, it is aimed to calculate the marketing margin and the profitability analysis of hazelnut production enterprises in Sakarya province. A survey was carried out in 152 farms operating hazelnut production in 6 provinces of Sakarya. Hazelnut garden size was found to be $12.13 \mathrm{da}$. The average yield of shell hazelnuts is $141.61 \mathrm{~kg} / \mathrm{da}$, the total cost of production is $714.27 \mathrm{€} / \mathrm{da}$, sum of varying costs is $596.30 € / \mathrm{da}$ and the cost of shell hazelnut is $5.044 \mathrm{f} / \mathrm{kg}$. Gross profit in per decar was 1 $440.05 €$ and net profit was 1322.08 . Marketing margin was calculated as $7.62 € / \mathrm{kg}$ for shell hazelnuts and $21.44 € / \mathrm{kg}$ for inner hazelnuts
\end{abstract}

Keywords: Hazelnut, Gross profit, net profit, marketing margins, Sakarya

\section{GİRIŞ}

Dünya'da yetiştiriciliği yapılan sert kabuklu meyvelerin başında findık gelmektedir (Anonim, 2012a). Türkiye ekonomisinde önemli bir yere sahip olan ve Türkiye'de 400000 findık işletmesinin geçim kaynağı olan findık, aynı zamanda Türkiye ihracatında da önemli bir yere sahiptir. Türkiye'nin toplam ihracatının \%2'sini, tarım sektörü ihracatının $\%$ 18'ini fındık ihracatı oluşturmaktadır. Türkiye dünya findık üretiminde ve ihracatında ilk sıradadır (Kızıltan ve Yalçın, 2010).

Dünya findık üretim ve ihracatında Türkiye'nin bu kadar büyük bir payı olmasına rağmen bu üründen arzu edilen ekonomik ölçüde yararlanıldığını söylemek mümkün değildir. Bunun iki temel nedeni olup, bunlardan birincisi işlenmiş findık ürünleri üretim ve ihracatının çok düşük olması, ikincisi ise Türkiye'nin geleneksel pazarı olan $\mathrm{AB}$ pazarı dışına çok az çıkılmasıdır (Sıray vd., 2015).

Türkiye'de kişi başına yıllık findık tüketimi 1 kg'ın altındadır. Ülkemizde findığın tüketimini artırmak için Fındık Tanıtım Grubu görevlendirilmiş, bu grup hazırladığı reklamlarla findık tüketimini özendirmeye çalışmıştır (Kızıltan ve Yalçın, 2010). Fındık insan beslenmesi dışında da çeşitli şekillerde tüketilmekte ve kullanılmaktadır (Anonim, 2012b). Fındık yağı kozmetik sanayisinde, serumlarda kolesterol seviyesini düşürmede (Reis ve Yomralıoğlu, 2005), dizel motorlarda performans ve emisyon özelliklerinin değişimini hızlandırmada kullanılmaktadır (Çelikten vd., 2012). Bununla birlikte yağı çıkarılan fındıktan ortaya çıkan küspe \%38-45 protein içerir ve hayvan yemi olarak yem sanayisinde kullanılmaktadır (Yavuz vd., 2004). Fındıkkabuğu ise endüstriyel kullanım alanı olan yenilenebilir bir yan üründür (Çöpür vd., 2006).

Fındık Türkiye'de İlk defa Doğu Karadeniz bölgesinde Giresun ilinde kültüre alınmıştır. 1964 yılında devletin alım garantisi vermesi ve diğer tarım ürünlerine göre daha az emekle elde edilmesi findık yetiştiriciliğini cazibeli hale getirmiştir. Doğu Karadeniz bölgesinden yapılan göçler sayesinde fındık yetiştirme kültürü Batı Karadeniz bölgesi ve diğer bölgelere de yayılmıştır (Anonim, 2014a). Çiftçi Kayıt Sistemine göre Türkiye'de 43 ilde findık yetiştiriciliği yapılmakta fakat ticarete konu olan fındık üretiminin tamamına yakını Doğu ve Batı Karadeniz ile Doğu Marmara bölgesindeki 14 ilde gerçekleşmektedir (Anonim, 2012b).

Türkiye'de, geliri sadece findığa bağlı olan üreticilerin gelirlerinde istikrar sağlamak, findığın kalitesinin yükseltilmek, meyilli arazilerde erozyonu önlenmek, iç ve dış piyasaları düzenlenme gibi amaçlarla findık 1964 yılında destekleme kapsamına alınmıştır. Devlet adına findık alımı için FISKOBİRLIK görevlendirilmiştir. 1994 yllına kadar yapılan destekleme alımlarında findık fiyatları genellikle maliyetlerin oldukça üzerinde belirlenmiş, bunun sonucunda findık üretimi meyilli arazilerin 
dışındaki taban alanlara doğru kaymıştır. Üretim alanı ve üretimdeki artışlar arz fazlalığına neden olarak üretici gelirlerinin düşmesine, stokların artmasına neden olmuştur (Aktaş vd., 2011).

Findik yıllarca devlet tarafindan desteklenip findık üreticilerinin geçim kaynağı olurken günümüzde artık yan gelir kaynağı haline gelmiştir. Stoklardaki fındıklar yağlık olarak değerlendirilmek üzere kırılmış ve yağlığa ayırma işlemi sonucunda oluşan zarar devlet tarafından üstlenilmiştir (Kızıltan ve Yalçın, 2010).

Fındığın ülkemiz açısından önemli bir stratejik konuma sahip olması, dünya üretim ve ihracat miktarını elimizde tutuyor oluşumuz fındık ile ilgili çalışmaları önemli kılmaktadır. Ayrıca Karadeniz bölgesi dişında önemli üretim merkezi olan Sakarya ve civarında fındık ile ilgili çalışmalar da önem arz etmektedir. Bu araştırmada Sakarya ilinde fındık üretim, tüketim ve pazarlama durumu ortaya konmuş, ayrıca Sakarya ilinde findık işletmelerinin demografik, sosyoekonomik ve tarımsal yapılarının tespiti ile brüt kar, net kar ve pazarlama marjının hesaplanması amaçlanmıştır.

Dünyada ve Türkiyede Fındık Üretim, Tüketim ve Pazarlama Durumu

Meyvesinden yaprağına kadar değerlendirilebilen ve tarım ekonomisi için büyük öneme sahip olan findığın üretimi ve pazarlaması büyük önem arz etmektedir. Fındık, kuzey yarım kürenin 1lıman iklim kuşağında her bölgede yetiştirilmektedir. 2014 yilında dünya findık üretiminde Türkiye $\% 65$ ile ilk sirayı alırken bunu sirasiyla İtalya (\%13), ABD (\%6), Gürcistan (\%5), Azerbaycan (\%4) ve İspanya (\%3) takip etmektedir. Geriye kalan \%4'lük kısmı ise diğer (Çin, İran, Yunanistan, Fransa, Rusya, Moldova vd) ülkeler oluşturmaktadır (Çizelge 1).

2014 yılında piyasaya arz edilen findığın \%15.66'llk kısmı içi piyasada tüketilmekte, \%2.41'i stoklanmaktadır. İhraç fiyatları yüksek olması durumunda, findık piyasasında Türkiye'ye rakip olan İtalya ve İspanya, AB'nin sağladığı destekler ve nakliye avantajlarını kullanarak daha düşük fiyatlarla satış yapmakta ve böylelikle stoklarını eritebilmektedirler. $\mathrm{Bu}$ nedenle devir stokları genellikle Türkiye de oluşmaktadır (Çizelge 2).

İhracatçı ülkelerin başında Türkiye gelmekte bunu sırasiyla İtalya, Azerbaycan, Gürcistan, ABD ve İspanya takip etmektedir (Çizelge 3). Üretici olmayıp ithal ettiği findığı, iç fındık veya işlenmiş fındık olarak ihraç eden ülkeler; Almanya, Fransa, Hollanda, Belçika, İsviçre, İngiltere, İrlanda, Bulgaristan, Macaristan ve Kanada'dır (Anonim, 2013b). Bu ülkelere re-export ülkeler denmekte olup fındığı Türkiye'den almaktadırlar. Bu da Türkiye'nin fındık piyasasında yeterince etkin olmadığını göstermektedir. Dünya findık ticaretinde Almanya findık üreten bir ülke olamamasına rağmen findık piyasasında çok etkili bir ülkedir. Bunun nedeni dünyada ki en büyük findık ithalatçı ve tüketici ülkelerden biri olmasının yanı sıra Türkiye ve İtalya'dan sonra findık ihraç eden önemli ülkelerden biri olmasıdır. Ayrıca fındık sanayisinin gelişmesi findık ithalatçısı firmaların tamamının Hamburg Borsası çatısı altında çok iyi örgütlenmiş olmaları Almanya'yı piyasada söz sahibi yapmaktadır (Yavuz vd., 2004).

Dünya findık ithalatında en büyük findık ithalatçısı ülkeler sırasıyla İtalya, Almaya, Fransa, Rusya, Belçika ve İsviçre'dir. Son yıllarda Polonya ve Kanada da önemli ithalatçı ülkeler sınıfına girmiştir (Çizelge 4). Çikolata ve şekerleme sanayisinin gelişmiş olduğu bu ülkeler aynı zamanda findığın ikamesi olan bademin de önemli alıcısı durumundadırlar (Anonim, 2013a; Anonim, 2014b).

Türkiye'de findık tarımı yapılan bölgeler üç gruba ayrılmaktadır. Fındık içi büyüklügü 13-15 mm olan Ordu, Giresun, Trabzon, Rize ve Artvin illeri 1. standart bölge, fındık içi büyüklügü 11-13 mm olan Samsun, Sinop, Kastamonu, Zonguldak, Bolu, Düzce, Bartın, Sakarya ve Kocaeli illeri 2. standart bölge, findık içi büyüklüğü 9-11 mm olan İstanbul, Bursa ve 25 kadar il 3. standart bölge olarak ayrılmaktadır. 3. standart bölge daha çok çerezlik olarak iç tüketimde kullanılmaktadır. Türkiye'de en kaliteli findık Giresun ilinde üretilmektedir. 


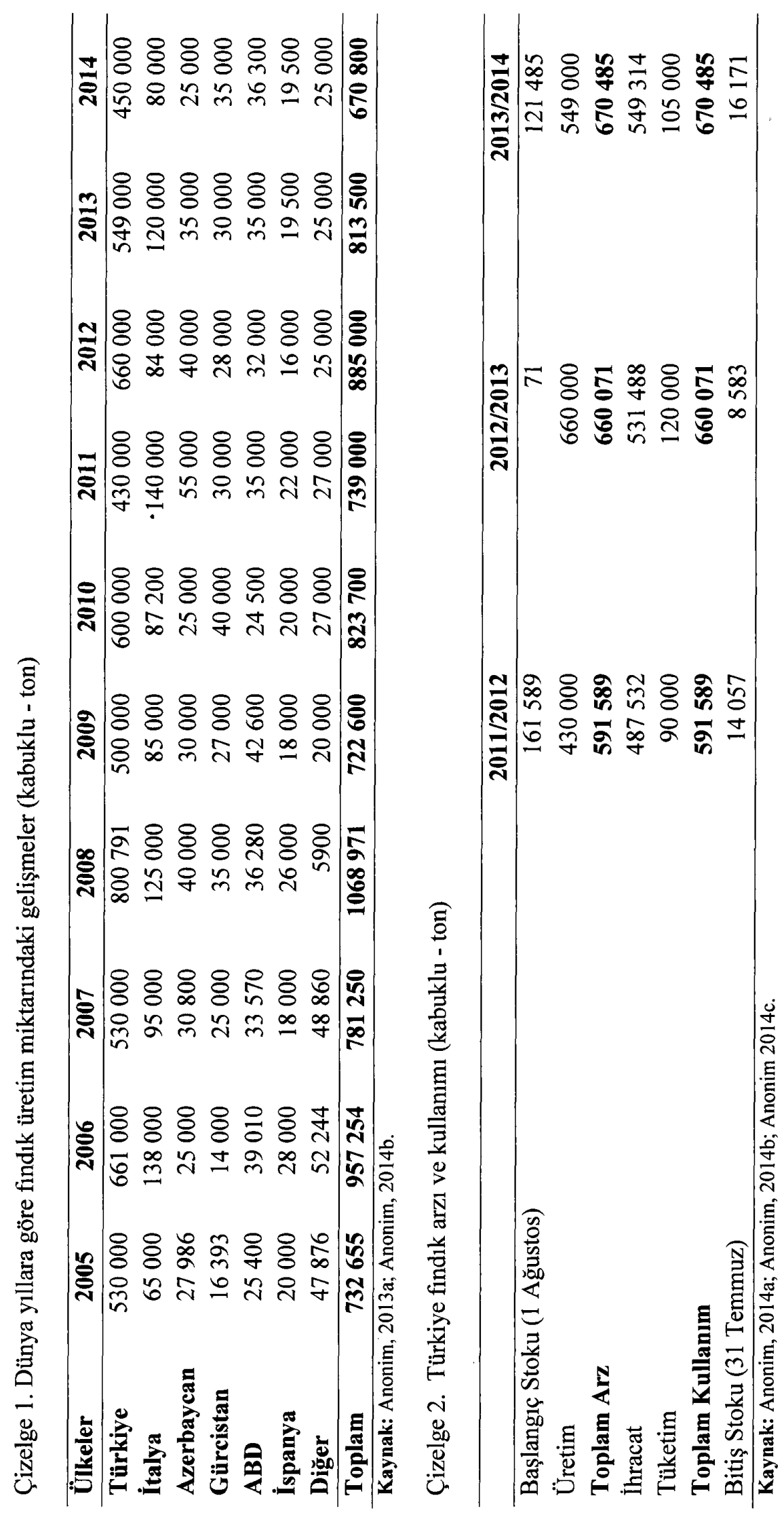




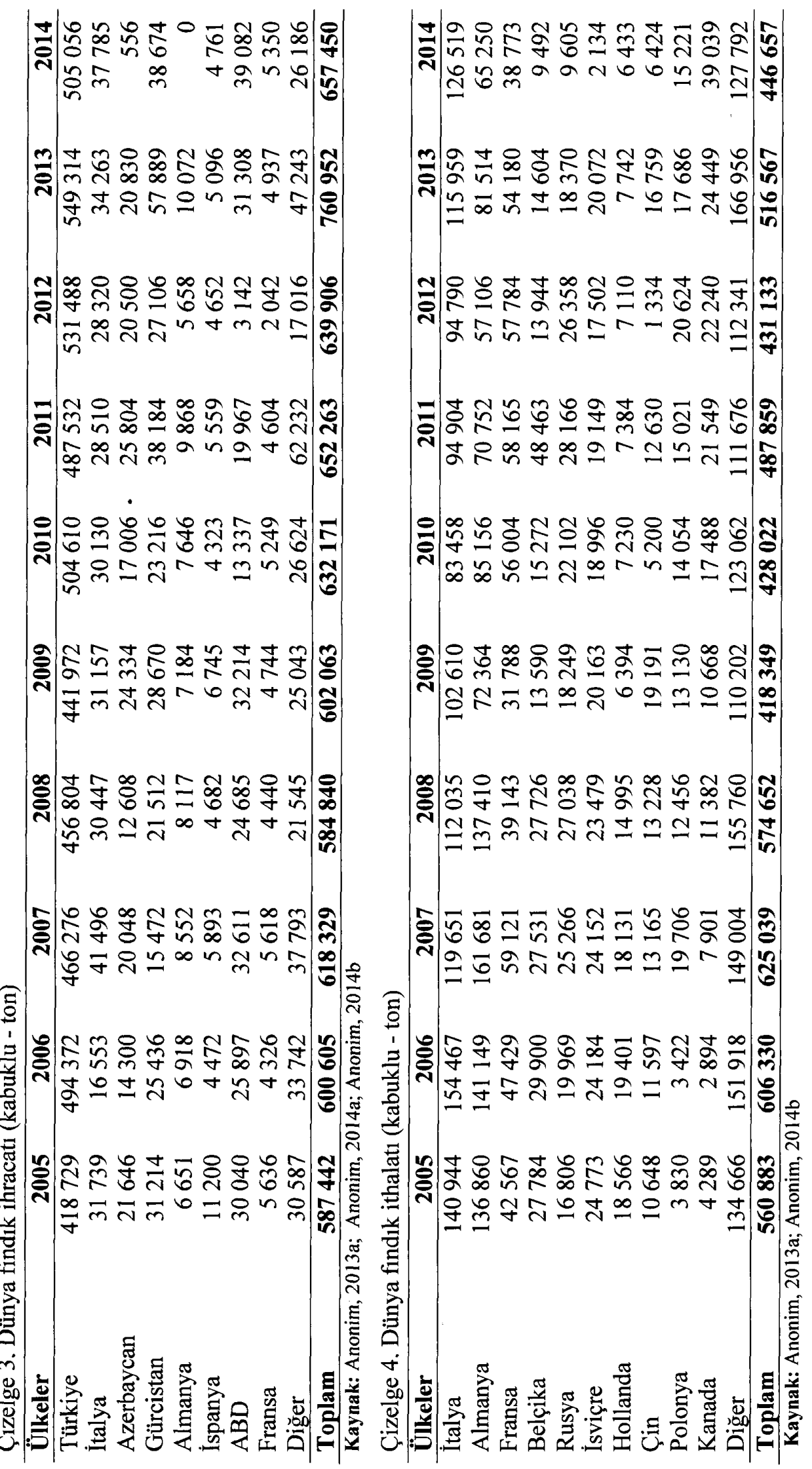


Çizelge 5. Türkiye'de yıllara göre il bazında findık üretim miktarı (kabuklu - ton).

\begin{tabular}{lrrrrrr}
\hline İller & $\mathbf{2 0 0 5}$ & $\mathbf{2 0 0 7}$ & $\mathbf{2 0 0 9}$ & $\mathbf{2 0 1 1}$ & $\mathbf{2 0 1 3}$ & $\mathbf{2 0 1 4}$ \\
\hline Ordu & 158605 & 174828 & 117751 & 99881 & 178357 & 84874 \\
Giresun & 83821 & 48457 & 68974 & 67603 & 81342 & 31567 \\
Samsun & 73467 & 37309 & 66617 & 52087 & 69392 & 73544 \\
Sakarya & $\mathbf{6 2} \mathbf{1 9 0}$ & $\mathbf{9 2 ~ 3 1 9}$ & $\mathbf{7 9 0 4 1}$ & $\mathbf{7 4 ~ 5 3 7}$ & $\mathbf{6 4 5 5 4 0}$ & $\mathbf{9 4 ~ 8 9 5}$ \\
Trabzon & 47862 & 37030 & 36802 & 34410 & 44537 & 31065 \\
Düzce & 57473 & 71699 & 72399 & 45098 & 48295 & 69503 \\
Zonguldak & 22880 & 36320 & 18478 & 20365 & 19105 & 30149 \\
Artvin & 295 & 7319 & 10439 & 9416 & 14420 & 9346 \\
Kocaeli & 11152 & 12679 & 13598 & 10649 & 8531 & 7323 \\
Kastamonu & 1996 & 3366 & 4025 & 4488 & 5102 & 4231 \\
Bartın & 1583 & 2274 & 3239 & 3683 & 5684 & 6688 \\
Rize & 910 & 1141 & 2159 & 2174 & 1377 & 1122 \\
Sinop & 1248 & 1634 & 1216 & 1092 & 1112 & 1078 \\
Gümüşhane & 221 & 196 & 225 & 758 & 876 & 876 \\
Diğer & 4301 & 3429 & 5037 & 4759 & 6330 & 3738 \\
\hline Türkiye & $\mathbf{5 3 0} \mathbf{0 0 0}$ & $\mathbf{5 3 0 ~ 0 0 0}$ & $\mathbf{5 0 0 ~ 0 0 0}$ & $\mathbf{4 3 0 0 0 0}$ & $\mathbf{5 4 9 0 0 0}$ & $\mathbf{4 5 0 0 0 0}$ \\
\hline
\end{tabular}

Kaynak: Anonim, 2014b Anonim, 2014c

Çiftçi Kayıt Sistemine göre Türkiye'de 43 ilde fındık yetiştiriciliği yapılmakta fakat ticarete konu olan findık üretiminin tamamına yakını 1. ve 2 . standart bölgede olan 14 ilde gerçekleşmektedir (Anonim 2012b). Türkiye'de findık üretimi 43 ilde yapılmasına karşın, üretimin tamamına yakın kısmı 6 ilde toplanmıştır (Çizelge 5). Bu iller; eski üretim bölgesi olarak adlandırılan Ordu, Giresun ve Trabzon ile yeni üretim bölgesi olarak adlandırılan Sakarya, Düzce ve Samsun illeridir.

Türkiye'de findık veriminde yıllara göre çok fazla dalgalanma olmaktadır. İklim şartları ve findık bitkisinde görülen periyodisite gibi etkenler verimde dalgalanmanın artmasına sebep olmaktadır. Son 10 yıllık findık üretim miktarının 611607 ton olduğu ve bu ortalamada en büyük payın 146849 ton findık üretimiyle yani yaklaşık \% $\% 6^{\prime}$ 'lı payla Ordu ilinin ilk sırada yer aldığ görülmektedir. Sakarya ise son 10 y1llık ortalamada 94076 ton üretimle yani yaklaşık \%29 payla ikinci sırada yer almaktadır. Fakat 2014 yılı üretim miktarlarına baktı̆̆ımızda Sakarya'nın 96 169 ton üretimle ilk sırada yer aldığ görülmektedir (Çizelge 5). Sakarya'nın 2014 yılında üretimde zirveye çıkmasının sebebi diğer bölgelere don vurması ile üretimin o bölgelerde düşük olmasından kaynaklanmaktadır.

\section{MATERYAL ve YÖNTEM}

\section{Materyal}

Araştırmada kullanılan birincil veriler, 2014 yılının Ekim-Kasım-Aralık aylarında Sakarya İli Akyazı, Hendek, Karasu, Kocaali, Ferizli, Kaynarca ilçelerinde 152 findık üreticisi ile yüz yüze yürütülen anket çalışmasından elde edilmiştir. Diğer taraftan konuyla ilgili yapılmış ulusal ve uluslararası araştırma makaleleri ve raporlar, Gıda, Tarım ve Hayvancılık İl ve İlçe müdürlüklerinin ÇKS kayıtları, konuyla ilgili istatistiki bilgiler ikincil veri kaynaklarını oluşturmuştur.

\section{Yöntem}

Araştırma alanı, Sakarya İlinde findık üretiminin yoğunlaştığı ve devletin findık üretim alanlarını sınırlama politikası ile sınırlandırdığı, üretim hakkı tanınan ilçeler temel alınarak belirlenmiştir. Gıda, Tarım ve Hayvancılık İl ve İlçe Müdürlüklerinden, findık üretim alanları ve işletme sayıları hakkında toplanılan kayitlar ve raporlar değerlendirilerek Sakarya İlinde araştırma alanı 6 ilçeyle sınırlandırılmıştır (Anonim, 2014d). Anket sayısının belirlenmesinde kullanılan eşitlik formül 1'de verilmiştir (Topcu vd., 2008; Aşkan ve Dağdemir, 2015).

$$
n=\frac{N p(1-p)}{(N-1) \sigma_{\hat{p}_{x}}^{2}+p(1-p)}
$$

$$
\begin{aligned}
& \text { Burada; } \\
& \mathrm{n} \quad: \text { Anket sayısı } \\
& \mathrm{N}: \text { Toplam işletme sayısı } \\
& \mathrm{p} \quad \text { : İşletmelerin seçilme olasılığı }(0,89) \\
& \sigma_{p_{x}}^{2}: \text { Varyans }
\end{aligned}
$$

Sakarya İlinde 24800 findık üretimi yapan aktif işletme olup \%95 güven aralığında anket sayısı 152 olarak hesaplanmış, çizelge 6'da gösterilmiştir. 
Çizelge 6. Sakarya'da Fındık İşletme Sayısı, Ekili Alan ve Anket Sayısı

\begin{tabular}{lccc}
\hline & İşletme Sayısı & Ekili Alan $\mathbf{( m}^{\mathbf{2}}$ & Anket Sayısı \\
\hline Kocaali & 7701 & 117381928 & 47 \\
Hendek & 5431 & 82773884 & 33 \\
Karasu & 4692 & 71520152 & 29 \\
Akyazı & 3586 & 54664537 & 22 \\
Ferizli & 2196 & 33473533 & 14 \\
Kaynarca & 1194 & 18207317 & 7 \\
6 ilçe Toplamı & $\mathbf{2 4 8 0 0}$ & $\mathbf{3 7 8 ~ 0 2 1 ~ 3 5 1}$ & $\mathbf{1 5 2}$ \\
Diğer ilçeler* & 3019 & 37040572 & 0 \\
\hline Toplam & $\mathbf{2 7 ~ 8 1 9}$ & $\mathbf{4 1 5 ~ 0 6 1 ~ 9 2 3}$ & $\mathbf{1 5 2}$ \\
(*Adapazarı (Sakarya merkez ilçe), Arifiye, Erenler, Geyve, Karapürçek, Pamukova, Sapanca, Serdivan, Söğütlü, Taraklı
\end{tabular}

Anket formları findık üretim ve pazarlaması amacına uygun olacak şekilde demografik, sosyoekonomik, tarımsal yapı ve pazarlama yapıs1 (pazarlama zinciri ve pazarlama marji) dikkate alınarak hazırlanmıştır. Fındık alıcısının findığı çiftlik avlusundan bizzat kendi gelip almasından dolayı önemli bir pazar maliyetinin de bulunmadığ 1 tespit edilmiştir

Çalışmada tek ürün bütçe analiz yöntemi kullanılmıştır. Bir üretim dönemindeki iktisadi faaliyetler sonucu elde edilen tarımsal çıktıların değerini ifade eden Gayrisafi Üretim Değerinden (GSÜD) değişen masrafların çıkarılmasıyla Brüt Kar ve üretim masraflarının çıkarılmasıyla da Net Kar hesaplanmıştır (Topcu, 2004; Aşkan, 2015).

$$
\begin{array}{ll}
\text { Brüt Kar } & =\text { GSÜD }- \text { DM } \\
\text { Net Kar } & =\text { GSÜD }- \text { ÜM }
\end{array}
$$

Bir malın çiftlik avlusu fiyatı ile aynı cins mal için tüketicinin ödediği (perakende) fiyat arasında az veya çok bir fiyat farkı vardır. Oluşan bu fiyat farkına "pazarlama marjı" denmektedir. Tüketicinin bir mal için ödediği fiyat ile üreticinin eline geçen fiyat oranı her bir mal için farklı olmaktadır. Ayrıca bir tarımsal ürünün işlenmeden direkt gıda olarak tüketiciye ulaştırılmasıyla oluşan pazarlama marjı işlenerek tüketiciye ulaştırılan bir gıdadan farklı olmaktadır. Genel olarak pazarlama marj1; "Tüketicinin herhangi bir ürünün bir kg’ı için ödediği fiyat ile bir kg nihai ürüne eşdeğer olan ilk ürün için çiftçinin eline geçen fiyat arasındaki fark" olarak tanımlanmaktadır. Pazarlama marjının hepsi kar olmayıp aracıların masrafların da ifade etmektedir (Dağdemir, 2014; Aşkan ve Dağdemir 2015).

Pazarlama marjının fonksiyonel formu aşağıdaki şekilde ifade edilmektedir.

Pazarlama Marj $=\mathrm{P}_{\mathrm{r}}-\mathrm{P}_{\mathrm{f}}$

$P_{f}$ : Tüketicinin satın aldığı birim ürüne eş değer çiftlik avlusu fiyatı

$\mathrm{P}_{\mathrm{r}}$ : Perakende seviyesinde bir birim ürün fiyatı

\section{BULGULAR ve TARTIŞMA}

Sakarya İlinde Findı Üreticilerinin Demografik ve Sosyo-ekonomik Yapısı

İşletmede alınan kararları etkileyen kişisel faktörlerden biri olan müteşebbisin yaşı, diğer fiziki, kişisel ve ekonomik özelliklerini dolaylı olarak etkilemektedir (Demir vd., 2012). Yapılan anketler sonucunda Sakarya'da findık üreticilerinin yaş ortalaması 44 olarak bulunmuştur (Çizelge 7). Bu da findık üreticilerinin ortalama bir yaşa sahip olduğunu ve findıkla ilgili yeterli bilgiye sahip olabileceklerini göstermektedir.

Çizelge 7. Sakarya'da Fındık üreticilerinin yaş durumu ve işletme sayıları

\begin{tabular}{lccc}
\hline Yaş Grupları & Yaş Ort. & İşletme Sayısı (n) & Yüzde (\%) \\
\hline $15-49$ & 35 & 95 & 62.5 \\
$50-65$ & 56 & 40 & 26.3 \\
$65+$ & 70 & 17 & 11.2 \\
\hline Toplam & $\mathbf{4 4}$ & $\mathbf{1 5 2}$ & $\mathbf{1 0 0 . 0}$ \\
\hline
\end{tabular}

Fındık üreticilerinin eğitim durumları ile yaş grupları arasındaki ilişkiye baktığımızda tüm yaş gruplarında okuma yazma bilmeyenler \%0.7, okuma yazma biliyor \%18.3, ilköğretim mezunu \%27.7, lise mezunu \%34.2 ve yüksek okul mezunu \%19.1'dir. Yüksekokul mezunlarının 15-49 yaş arası grupta yoğunluk gösterdiği tespit edilmiştir. Sakarya'da fındık üreticilerinin başka işler yaptı̆̆ı, tamamen fındık tarımına yönelik bir yaşam tarzlarının olmadığı, yüksekokul mezunu ve başka meslek dallarından birçok üreticinin olduğu tespit edilmiştir. Yüksekokul mezunlarının oransal olarak fazla 
çıkması, fındığın diğer tarım ürünleri gibi araziye bağlayıcı özelliğinin olmaması ve çoğu findık üreticisinin atadan kalma bahçelere bakmasından kaynaklanmaktadır.

Sıray (2010) Giresun ili merkez İlçede fındık yetiştiren işletmelerle yaptığı çalışmayı ilk kuşak ve yüksek kuşak diye iki gruba ayırmıştır. İlk kuşak ve yüksek kuşakta eğitim durumu sırasıyla ilkokul mezunlar1 \%44.37 ve \%51.61, üniversite mezunları ise $\% 9.53$ ve $\% 4.17$ bulunmuştur. Sakarya ilinde yüksekokul mezunları çok daha fazla bulunmuştur.

İşletmelerin \%88.8'inin (Bağ kur \%64.5, SSK $\% 5.3$ ve emekli sandiğ $1 \% 19.0$ ) sosyal güvencesi var iken \%11.2'sinin olmadığ 1 belirlenmiştir. Üreticilerin $\% 83.6$ 'sının tarım dışı gelirinin olduğu \%16.4'ünün tarım dışı gelirinin olmadığ 1 ve tüm geçimini tarımdan sağladığ 1 tespit edilmiştir. Üreticilerinin ortalama aylık gelirlerinin $3 \quad 376 \quad$ E olduğu hesaplanmıştır.

\section{Sakarya İlinde Fındık Üreten İşletmelerin} Tarımsal Yapısı ile İlgili Bulgular

Araştırma bölgesinde işletme başına düşen arazi miktarı 37.2 da olarak hesaplanmıştır. İşletme başına düşen findık bahçesi ortalama 12.13 da hesaplanmış olup işletmelerin \%65.82'sinin 10 da altındaki fındık bahçesine sahip olduğu belirlenmiştir.

Sıray (2010) Giresun ilinde yaptığı çalışmada findık bahçesini ortalama olarak ilk kuşakta 27.59 da, yüksek kuşakta ise 29.91 da olarak bulmuştur. Fındık bahçesinin Sakarya'dan yüksek çıkma sebebi, Giresun'da arazinin başka alternatif kullanımının az olmasından dolayı sahip olunan arazinin tamamina yakınını findık üretiminde kullanılmaktadır.

Findık bahçelerinin kurulduktan sonra genellikle 4 yıl içerisinde ürün verdiği ve findık bahçelerinin ortalama yaşının 22.8 olduğu belirlenmiştir. Üreticilerin \%87.5'inin findik satış fiyatından memnun olduğu, \%12.5'inin ise memnun olmadığ 1 tespit edilmiştir. Yine üreticilerin $\% 69.1$ 'inin findık girdi fiyatından memnun olduğu, \%30.9'unun ise memnun olmadı ̆̆ 1 bulunmuștur.

$\mathrm{Bu}$ verilere göre üretici kabuklu findık kg başına (14.38 - 5.044) 9.336 € kar elde etmektedir.

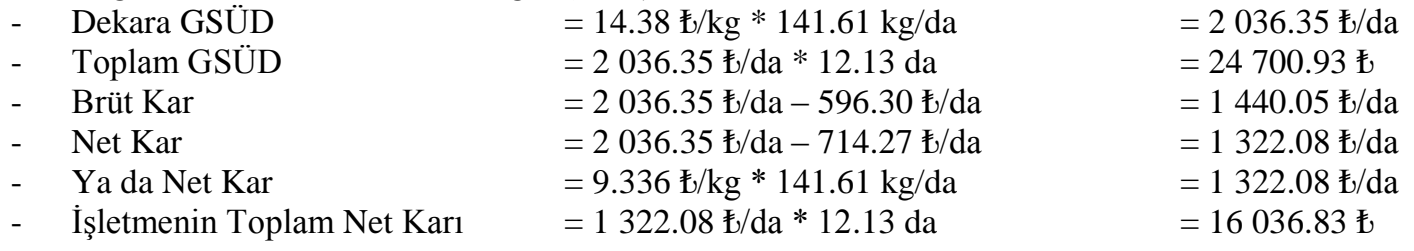

Sıray (2010) yaptı̆̆ çalışmada ilk kuşak ve yüksek kuşakta kabuklu findık brüt karı ortalama olarak sirasıyla $38.19 € /$ da ve $52.99 € /$ da, net karı ise iki kuşakta da önemli oranda zarar bulmuştur. Brüt karın çok düşük olduğu görülmektedir.
İşletmelerin \%76.3'ü fiyatın randımana göre belirlenmediğini belirtmişlerdir. Sakarya'da kabuklu fındık randıman oranı \%57.9 olarak bulunmuştur. Fiyatın randımana göre şekillenmesi piyasa findık fiyatının homojen bir yapıya sahip olmasını sağlamaktadır.

İşletmelerin \%94.1'inin ürettiği findığ tüccarlara, \%3.3'ünün kooperatiflere, \%2.6'sının ise işleyici fabrikalara sattığı belirlenmiştir. Ayrıca fındık alıcılarının genellikle findığı gelip kendileri aldığ1 ve çoğu işletmenin önemli bir pazar maliyetinin olmadığ 1 tespit edilmiştir.

\section{Brüt Kar ve Net Kar}

Sakarya'da yapılan anketler sonucunda yapılan hesaplamalarda; kabuklu findik ortalama verim $141.61 \mathrm{~kg} / \mathrm{da}$, üretim masraflar toplamı $714.27 \mathrm{\ddagger} / \mathrm{da}$, değişir masraflar toplamı 596.30 €/da, kabuklu findık maliyeti (714.27 / 141.61) 5.044 €/kg, kabuklu findık çiftçi satış fiyatı ise $14.38 \mathrm{z} / \mathrm{kg}$ olarak hesaplanmıştır.

Sıray (2010) 2008 y1lı verilerine dayandırarak yaptığı çalışmada, ilk kuşak ve yüksek kuşakta kabuklu findık verimini ortalama olarak sirasıyla $131.44 \mathrm{~kg} / \mathrm{da}$ ve $111.44 \mathrm{~kg} / \mathrm{da}$, maliyeti sirasiyla 7.91

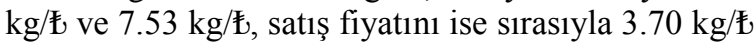
ve $4.04 \mathrm{~kg} / \mathrm{f}$ olarak bulmuştur. Giresun'da verim Sakarya iline göre düşük çıkmış, yüksek kuşakta daha da düşük bulunmuştur. Sakarya'da iklim ve toprak yapısının verimi yükselttiği söylenebilir. Sıray'ın yaptığı hesaplamalarda maliyet çok yüksek satış fiyatı ise maliyetin çok altında hesaplanmıştır. Maliyetin çok yüksek olma sebebi sabit masrafların çok yüksek olmasından, ayrıca da hem sabit hem de değişir masraflarda itibari (iç) masrafların çok yüksek olmasından kaynaklanmıştır.

Gayrisafi Üretim Değeri findık satışından elde edilen toplam geliri ifade etmektedir. Bu da kabuklu fındık çiftçi satış fiyatının findık miktarı ile çarpılması sonucu bulunmaktadır. belirlendiğini, \%23.7'si ise fiyatın randımana göre

Halbuki yaptığımız çalışma göstermektedir ki; Sakarya'da fındık üretiminin yoğun işgücü ve zamana ihtiyaç duymaması yöre çiftçisinin alternatif işlerini yapmasına engel olmamakta findıktan da önemli bir gelir elde etmektedirler. 


\section{Pazarlama Marjı}

Çalışma sonucunda Sakarya ilinde üretilen findık için 3 alternatif pazarlama kanalı olduğu belirlenmiş ve aşağıda verilmiştir.

- Üretici $\rightarrow$ Tüketici

- $\quad$ Üretici $\rightarrow$ Perakendeciler $\rightarrow$ Tüketici

- Üretici $\rightarrow$ Fındık Kırıcı Fabrikalar $\rightarrow$ Perakendeciler $\rightarrow$ Tüketici

Yapılan anketler sonucunda kabuklu findık çiftçi satış fiyatı $14.38 \mathrm{£} / \mathrm{kg}$ olarak hesaplanmıştır. Resmi kurumlardan alınan veriler ile 2014 y 11 kabuklu findık piyasa satış fiyatı $22.00 € / \mathrm{kg}$, findık kırıcı fabrikalarının üreticiden aldıkları kabuklu fındığı iç findığa dönüştürdükten sonra perakendecilere satış fiyatı $37.00 \mathrm{f} / \mathrm{kg}$, iç findığın tüketiciye satış fiyatının ise $46.27 \mathrm{€} / \mathrm{kg}$ olduğu belirlenmiştir (Anonim 2014e).

- Kabuklu findığın pazarlama marjı; 22.00 $14.38=7.62 \mathrm{f} / \mathrm{kg}^{\prime}$ 'dır.

$1 \mathrm{~kg}$ iç findık $1.727 \mathrm{~kg}$ kabuklu findıktan (\%57.9 randıman) elde edilmektedir. Buna göre $1 \mathrm{~kg}$ iç findığın eşdeğeri olarak çiftçi eline geçen fiyat (1.727 $\mathrm{kg} * 14.38) 24.83$ €'dir.

- İç findık pazarlama marjı; $46.27-24.83=$ 21.44 €/kg'dır.

Tüketicinin $1 \mathrm{~kg}$ kabuklu findığa ödediği paranın \%65.36'sı üretici, \%34.64'ü ise aracılar eline, tüketicinin $1 \mathrm{~kg}$ iç findığa ödediği paranın $\% 53.66$ 's1 üretici, \%46.34'ü ise aracilar eline geçmektedir. $1 \mathrm{~kg}$ iç fındığın pazarlama marjı olan 21.44 £’nin 12.17 €’si findık kırıcı fabrikaları ile üretici arasında, 9.27 €'si ise tüketici ile findık kırıcı fabrikalar arasındadır.

\section{SONUC}

Araştırma sonuçlarına göre Sakarya'da findık üreten işletmelerde findık gelirinin yan gelir niteliğinde olduğu ortaya çıkmaktadır. Diğger taraftan yan gelir olmasına rağmen önemli bir gelir de elde edilmektedir. Bu bölgede findık çiftçisi daha itinalı bir şekilde her yönü ile findıkta uzman olduğu takdirde tekel konumunda olunan findiktan daha fazla katma değer ve döviz girdisi sağlamak mümkündür.

Ayrıca hesaplanan findık maliyeti ve kar hesaplamaları göstermektedir ki üretiminde dünya lideri olduğumuz findığa tüketicinin ödediği fiyat çok yüksektir. $\mathrm{Bu}$ durumun tüketici lehine geliştirilen politikalarla ortadan kaldırılması ve yurt içinde daha makul fiyatlarla tüketiciye daha fazla findık tüketim firsatı verilmelidir.

\section{KAYNAKLAR}

Aktaş, A.R., Öztürk, E. ve Hatırlı, S.A., 2011. Türkiye Fındık Tarımında Kar Etkinsizliğinin Analizi. Tarım Bilimleri Dergisi, 17, s.230-240.

Anonim, 2012a. www.faostat.com.

Anonim, 2012b. Findık Durum ve Tahmini, Tarımsal Ekonomi ve Politika Geliştirme Enstitüsü, TEPGE Yayın No:221.

Anonim, 2013a. Uluslararası Findık Konseyi

Anonim, 2013b. 2012 Yılı Fındık Raporu. T.C. Gümrük ve Ticaret Bakanlığı, Kooperatifçilik Genel Müdürlüğü, Ankara.

Anonim, 2014a. 2013 Yilı Findık Sektör Raporu, Toprak Mahsülleri Ofisi Genel Müdürlüğü, Ankara.

Anonim, 2014b. www.tuik.com.tr

Anonim, 2014c. Karadeniz İhracatçılar Birliği (KİB).

Anonim, 2014d. Sakarya Tarım İl ve İlçe Müdürlükleri.

Anonim, 2014e.Türkiye Ziraat Odası Birliği Fındık Fiyatları.

Aşkan, E., 2015. TRA1 Düzey 2 Bölgesinde Destek ve Teşvik Alan Süt Sı̆̆ırcılığı İşletmelerinin Ekonomik Analizi. Atatürk Üniversitesi Fen Bilimler Enstitüsü. Doktora Tezi.

Aşkan, E. ve Dağdemir, V., 2015. Türkiye Sarımsak Piyasasının Ekonomik Analizi. Alınteri Zirai Bilimler Dergisi, 28(B), 19-26.

Çelikten İ., Solmaz, H. ve Mutlu, E., 2012. Fındık Yağının Dizel Motor Performansı ve Emisyonu Etkisi, Gazi Üniversitesi, Ankara.

Çöpür, Y., Güler, C., Akgül, M. ve Taşcıoğlo, C., 2006. Fındık Kabuğunda ki Kimyasalların Alternatif Ürün Üretimi İçin Uygunluğu, Abant İzzet Baysal Üniversitesi, Düzce.

Dağdemir, V., 2014. Tarımsal Pazarlama Ders Notları (Basılmamış).

Demir, O. ve Gözübüyük, Z., 2012, Erzurum Yöresinde Çiftçi Ailelerinin Yaşam Standartlarının ve Bunu Etkileyen Sosyoekonomik Faktörlerin Tespiti. Atatürk Üniversitesi Ziraat Fakültesi Dergisi, 43(2): 141-147.

Kızıltan, A. ve Yalçın, H., 2010. Türkiye'de Fındık Sektöründe Üreticilerin Sorunlar1: Samsun İlinde Bir Uygulama. Atatürk Üniversitesi İktisadi ve İdari Bilimler Dergisi, Cilt: 24, Say1: 4, s.79-98.

Reis, S., ve Yomralığlu, T., 2005. Tahıl ve Fındık Bozulmasını Önlemek İçin Güvenli Depolama ve Kurutucu Tasarımı, Karadeniz Teknik Üniversitesi, Trabzon.

Sıray, E., 2010. Giresun İli Merkez İlçede Fındık Yetiştiren İşletmelerin Ekonomik Analizi, Üretim ve Pazarlama Sorunlarının Belirlenmesi Üzerine Bir Araştırma. Gaziosmanpaşa Üniversitesi Fen Bilimleri Enstitüsü. Yüksek Lisans Tezi. Tokat.

Sıray, E., Özdemir, F., Duyar, Ö., Erol, H., Sayılı, M. ve Akçay, Y., 2015. Fındık Yetiştiren İşletmelerin Ekonomik Analizi: Giresun İli Örneği. Gaziosmanpaşa Üniversitesi Ziraat Fakültesi Dergisi, 32 (2), s.64-78.

Topcu, Y., 2004. A study on the meat cost and marketing margings of cattle fattening farms in Erzurum province. Turk J. Vet Anim. Sci., 28(6):1007-1015.

Topcu Y., Uzundumlu A., S. ve Kızıloğlu, S., 2008. Sığır Besiciliği İşletmelerinin Başarısızlığında Etkili Faktörlerin Analizi; Erzurum İli Örneği. Alınteri Dergisi, s. 19-25, 2008.

Yavuz, F., Birinci A., Peker K. ve Atsan T., 2004. Türkiye Fındık Sektörü Ekonometrik Modelinin Oluşturulması ve Politik Analizlerde Kullanımı, No:113, Erzurum. 